\title{
SUPPLY-DEMAND SHOCKS AND GOVERNMENT RESPONSE TO PANDEMIC ISSUES (EXAMPLE OF GEORGIA)
}

\author{
Raisa Khachaturian, Academic Doctor of Economics, Associate Professor of Samtskhe-Javakheti \\ State University; Associate Professor of Georgian National University SEU, Georgia \\ DOI: https://doi.org/10.31435/rsglobal_conf/25112020/7240
}

\begin{abstract}
In this article, it is discussed the main threats and consequences of the cause of the modern economic crisis - the coronavirus pandemic - that have affected the macroeconomic situation in different countries and regions of the world. The focus is on the radical international economic changes that have caused supply and demand shocks, which have conditioned the structural nature of the crisis. The negative consequences of the pandemic in different sectors of the world are analyzed and general tendencies related to foreign trade, protectionism, employment, fiscal, monetary and other policies are listed.

It describes the anti-crisis economic plan developed by the Georgian government and provides examples related to corporate tax shelters.

Finally, the conclusion stresses that the priority of the post-crisis economic plan should be to position the country well after the end of the pandemic, as well as to overcome macroeconomic problems such as current account deficits, public debt, unemployment and poverty, rapid economic growth, competitiveness and etc.
\end{abstract}

Keywords: pandemic, demand shock, supply shock, crisis, government decision.

Introduction. The coronavirus pandemic has become a major cause of the modern economic crisis, the depth and severity of which has not yet been fully realized. First, this uncomfortable event is a difficult challenge to global health, but at the same time it poses a significant threat to the global economy. The fact that several processes are merging at the same time complicates matters. The world is in a crisis zone. At first glance, this may seem common, but it should also be noted that the global economic crisis of the last 300 years was not caused by medical problems.

The pandemic first led to the severing of economic ties, the closing of borders and the banning of mass events. All this led to a shock in deliveries. The last time a similar situation occurred in the world was in the 1970s, when the countries of the Arab world imposed an oil embargo. ${ }^{1}$ In turn, the current supply shock is caused by a sharp decline in capital and labor resources, which has led to the closure of enterprises, individual regions, and countries as a whole. In addition, due to restrictions imposed on the operation of transport communications and the logistics chain, the fertility of common factors has also declined.

Purpose. It should be noted that in addition to the supply shock, there is also a demand shock. From an international economic point of view, this is reflected in the declining demand for export goods for export-oriented countries. Consequently, the demand for imports from other countries is decreasing. In addition, there is a decrease in domestic demand, which is mainly due to the devaluation of monetary units and the reduction in the purchasing power of the population. For example, in Georgia in March 2020, the Georgian Lari reached an unprecedented level - $\$ 1=$ 3.48 GEL, however, the situation has relatively improved and the national currency against the dollar in recent months (June-August) remains in the range of 3.00-3.07. ${ }^{2}$

Research methods. The combination of supply and demand shocks is an essential feature of the global crisis and predetermines its structural nature. Practice has shown that such crises do not occur very often. They are based on technological advances that lead to a serious renewal of economic, socio-political, intellectual and ideological living conditions. The new structural crisis caused by the coronavirus is radically changing the paradigm of public life. In the normal economic world, the situation changes daily. Therefore, in developing an anti-crisis program, both the extreme

\footnotetext{
${ }^{1}$ Raisa Khachaturian, "Global Economic Equilibrium in Transition” Tbilisi, publishing house "Basiani", p. 35, 2009

${ }^{2}$ Retrieved from https://www.nbg.gov.ge
} 
tasks of neutralizing the devastating consequences of the spread of the coronavirus and the mediumterm structural challenges shaping the contours of the new socio-economic realities must be considered. Long-term trends require a separate analysis. Currently, the most important thing is to take anti-crisis measures and implement them. Governments and experts from all countries are working together to fight against a double blow: a pandemic and an economic crisis.

First of all, there is a need to understand the economic challenges created by governments, to manage medical threats and humanitarian tasks, under resource-constrained conditions, launch of economic benefits and stimulus packages, define the timing of the crisis, accelerate e-government reforms, develop existing platforms and increase their accessibility, and generally provide financial assistance to those in demand and thus support manufacturers. On the other hand, it is necessary to understand the positive and negative international experience in dealing with the economic crisis, to alleviate administrative pressure on companies, to eliminate excessive controls. In this regard, it is necessary to mention the timely and important response of the Government of Georgia, which is linked to the decision taken in April of this year to provide goods for healing/medical purposes and/or to exempt imports from VAT. By the joint order of the Minister of Finance and the Minister of IDPs from the Occupied Territories, Labor, Health and Social Affairs, the supply and/or import of the following goods shall be exempt from VAT until 1 October 2020: safety face shields, polythene shoe covers, disposable gloves, disposable insulating clothing, the packaging of medical gowns, disposable cap and polythene shoe covers, plastic goggles, medical veils and masks, non-contact forehead thermometers. ${ }^{1}$ The mentioned decision, in addition to helping the health sector to combat the pandemic smoothly, increases the demand for this product category. The government of our country has also implemented several measures - anti-crisis plans have been drawn up in various ministries and agencies, among which the anti-crisis economic plan is remarkable from a macroeconomic point of view. According to the plan, the fight against the pandemic was conducted in two directions: to save the health of citizens, life and the Georgian economy. In the first phase of the plan, emergency assistance was provided to citizens and entrepreneurs, taxes were deferred for 4,500 companies, insurance on the price of building materials was provided for infrastructure projects, etc. However, the pandemic still had a negative impact on the country's economy, resulting in a $4 \%$ slowdown in economic growth of $4 \%$, a reduction of budget revenues by 1.8 billion GEL and a reduction of current expenditures by 300 million GEL. ${ }^{2}$ Under the coronavirus conditions, the Eurozone economy also faced a simultaneous supply and demand shock. The global value chain, in which China played a leading role, was severely affected by the pandemic, which had a negative impact on the macroeconomic situation of countries around the world. China's production has fallen sharply, leading to a slowdown in imports of consumer goods and industrial raw materials; as a result, the supply chain of European companies has been directly or indirectly disrupted. At the same time, the joint demand has been reduced. The closure of China and the economic slowdown have led to a decline in demand for European goods or capital. In addition, domestic demand for non-primary productions declined. ${ }^{3}$

The pandemic has had a negative impact on many sectors of economies of leading countries: manufacturing, the financial sector, tourism, retail, leisure and entertainment. Automobile and electrical appliance manufacturers, stock exchanges and financial markets have been particularly badly affected. As a result, the demand for long-term, non-primary production has decreased. As for the service sectors such as hotels, restaurants, cinema and theatre, they found themselves in a state of social distancing at the earliest possible moment and in a state of shock in relation to demand. Demand for clothing and accessories decreased in the retail sector and increased in everyday items such as groceries, cleaning products and medicines. However, the biggest impact of the coronavirus was on the tourism and transportation sector. There has been both a supply and a demand shock. Considering the current situation, it is difficult to define precise estimates, the same losses, we will therefore refrain from any statistical data at this stage of the study. As for Georgia, despite the benefits received in the field of tourism (and in case of suspension of activities in general $)^{4}$, it has also suffered great losses in this sector. Since this sector occupies a large share

\footnotetext{
${ }^{1}$ See details. on rs.ge

${ }^{2}$ Retrieved from https://stopcov.ge

${ }^{3}$ Retrieved from http://www.parliament.ge/ge/kvleviti-centri

${ }^{4}$ According to the decision made by the Government of Georgia, persons operating in the tourism sector, as well as those business entities that have suspended their activities due to the current situation, have the opportunity to defer declared tax liabilities in the income and property tax part for 4 months, until November 1 of this year. rs.ge
} 
of the Georgian economy and, therefore, economic growth is largely due to tourism, we can conclude that the country in terms of macro-indicators will be unfavorable for some time.

Research results. The economic consequences of the coronavirus pandemic have varied from region to region and country to country, although we can outline the general tendencies that will emerge soon:

- Free foreign trade and globalization, which have become a major focus of international cooperation since China's accession to the World Trade Organization in 2001, will be replaced by protectionism. Industrial activity and employment will be reduced worldwide, contributing to the independence and self-sufficiency of countries, although there will be concomitant inefficiencies. Protectionism may have led to an increase in jobs and thus incomes within countries, although the realities of the 1930s showed that trade barriers reduce economic growth and lead to deflation.

- Consumer attitudes towards the purchase and use of certain types of goods and services, which are essential to life, will last for a long time. This, in turn, will be reflected in consumer expenditures and, consequently, in retail sales. In addition, fiscal stimulus will be increased as monetary policy becomes ineffective.

- With the exception of total protectionism, global supply will far exceed global demand. As a result, excess savings will lead to lower inflation and interest rates. Low inflation and falling prices will weaken people's desire to buy more, further hampering the process of economic recovery.

- According to Bloomberg, the global economy will lose more than $\$ 5$ trillion over two years due to the coronavirus pandemic, which, in comparison, is equivalent to the annual volume of Japanese production. He also notes that the world is experiencing its worst recession since peacetime in the 1930s, as the spread of the virus has forced countries to shut down most of their businesses. According to a Bloomberg forecast, although the slowdown will be short-term, it will take a long time for economies to recover from the loss. Despite unprecedented levels of monetary and fiscal stimulus gross domestic product will not be able to return to its pre-crisis level by 2022. According to World Trade Organization experts, the decline in world trade this year could be more than $30 \% .{ }^{1}$ Therefore, all this indicates that in many countries of the world, both supply and demand shocks will occur for a long time still.

Conclusions. Taking all the above into account, it can be said that macroeconomic stimulus policies today require particular caution. Supply and demand shocks in different countries imply different sets of anti-crisis measures. For example, it is generally known that financial injections lead to an increase in demand, but at the same time have a negative impact on the conditions for supply shocks and create conditions for stagflation. To avoid such a scenario, a new long-term strategic plan for the economic environment should be developed based on the specificities of the State in the different countries of the world. The Government of Georgia, in cooperation with a high-level advisory group of experts, has already started to work intensively on a plan for a rapid exit from the economic crisis. The priorities of this post-crisis economic plan are: to successfully position the country on the world economic map after the end of the pandemic; to overcome macroeconomic problems such as current account deficits, public debt, unemployment and poverty, rapid economic growth and competitiveness, etc.; Successful implementation of the listed priorities will enable the State to radically change the situation and increase the level of confidence. For confidence is the most important economic category, the lack of which causes many macroeconomic problems, including supply and demand shocks.

\section{REFERENCES}

1. Raisa Khachaturian, "Global Economic Equilibrium in Transition” Tbilisi, publishing house "Basiani", 2009

2. Retrieved from https://www.nbg.gov.ge

3. Retrieved from rs.ge

4. Retrieved from stopcov.ge

5. Retrieved from http://www.parliament.ge/ge/kvleviti-centri

6. Retrieved from rs.ge

7. Retrieved from https://www.rbc.ru/economics/09/04/2020

\footnotetext{
${ }^{1}$ Retrieved from https://www.rbc.ru/economics/09/04/2020
} 